\title{
Penerapan model problem based learning (PBL) untuk menumbuhkan kreativitas belajar dalam mata pelajaran PPKn
}

\author{
Yayinta Maharani Puspita Putri ${ }^{a, 1^{*}}$, Yogi Nugraha ${ }^{b, 2}$, Tridays Repelita ${ }^{c, 3}$ \\ abcPendidikan Pancasila dan Kewarganegaraan, Universitas Buana Perjuangan Karawang, Indonesia \\ ${ }^{1}$ pk16.yayintaputri@mhs.ubpkarawang.ac.id* \\ *korespondensi penulis
}

\begin{abstract}
ABSTRAK
Penelitian ini untuk mengkaji apakah penerapan model Problem Based Learning (PBL) untuk menumbuhkan kreativitas belajar dalam mata pelajaran PPKn di kelas X Akuntansi 4 SMKN 2 Karawang. Penelitian ini mengkaji apakah model PBL dapat menumbuhkan kreativitas belajar dalam pelajaran PPKn. Pendekatan menggunkan pendekatan kualitatif dengan metode observasi, dan wawancara. Pengumpulan data dilakukan dengan menggunakan instrument wawancara secara daring menggunaka google from. Subjek dalam penelitian ini adalah 1 orang guru PPKn di kelas X Akuntansi 4, 1 orang guru PPKn kelas XI, 4 siswa kelas X Akuntansi 4 di SMKN 2 Karawang. Teknik analisis data menggunakan pengumpulan data, reduksi data, dan penyajian data. Hasil penelitian menunjukan bahwa model PBL dapat digunakan untuk meningkatkan kreativitas belajar dalam mata pelajaran PPKn di kelas X Akuntansi 4. Model PBL ini menjadikan siswa lebih kreatif, aktif, dan berani menyampaikan gagasannya dalam berdiskusi kelompok belajar dimana siswa mempersentasikan hasil diskusi menggunakan slide power point yang kreatif.
\end{abstract}

\begin{abstract}
This research is to examine the application of Problem Based Learning (PBL) model to foster the creativity of learning in the subject of PPKn in class X accounting 4 SMKN 2 Karawang. This approach uses a qualitative approach with observation methods, and interviews. Data collection is done by using online interview instruments use Google from. The subject in this study was 1 teacher of PPKn in grade $X$ accounting 4, 1 teacher of PPKn class XI, 4 students $X$ Accounting 4 in SMKN 2 Karawang. Data analysis techniques using data collection, data reduction, and data presentation. The results showed that the PBL model can be used to improve the creativity of learning in the subject of PPKn in grade X accounting 4. The PBL Model makes students more creative, active, and dare to convey their ideas in a study group discussion in which students are centrying the results of the discussion using creative power point slides.
\end{abstract}

Sejarah Artikel

Diterima: 15 Mei 2020

Disetujui: 25 Juli 2020

Kata kunci:

PPKn

Problem Based Learning

Kreativitas Belajar

Article's Information:

Received: 15 May 2020

Approved: 25 July 2020

Keywords:

Civic Education

Problem Based Learning

Creativity Of Learning

\section{Pendahuluan}

Belajar adalah aktivitas yang selalu melibatkan proses berfikir. Belajar juga selalu dikatakan sebagai kreativitas dalam kegiatan yang berlangsung dilingkungan kehidupan sehari-hari yang menghasilkan perubahan dalam perlakuan, pengetahuan-pengetahuan, keterampilan, dan nilai sikap. Pada saat proses pembelajaran harus menggunakan model, strategi, dan media pembelajaran yang sesuai supaya menumbuhkan minat belajar siswa yang yang tinggi. Pada saat proses kegiatan belajar megajar di kelas, guru sudah seharusnya memiliki strategi dalam pembelajaran agar siswa dapat belajar secara efektif, efesien, kreatif, dan mencapai tujuan yang diharapkan oleh guru. Salah satu langkah untuk memilki strategi itu harus menguasai teknik-teknik penyajian atau disebut model pembelajaran. Model pembelajaran mempunyai peran yang sangat penting dalam kegiatan belajar dan mengajar karena penggunaan model pembelajaran merupakan bagian yang harus mendapat perhatian guru dalam setiap kegiatan pembelajaran. Model digunakan untuk memecahkan suatu 
masalah yang dihadapi ataupun untuk menjawab suatu pertanyaan yang berbeda, dengan model yang digunakan untuk tujuan agar siswa mampu berfikir dan mengemukakan pendapat sendiri.

Pendidikan kewarganegaaan termasuk pendidikan demokrasi yang bertujuan untuk mempersiapkan warga masyarakat berpikir kritis dan bertindak demokratis, melalui aktifitas menanamkan kesadaran kepada generasi baru, tentang kesadaran bahwa demokrasi adalah bentuk kehidupan masyarakat yang paling menjamin hak-hak masyarakat. Sesuai dengan Pasal 3 UndangUndang Nomor 20 tahun 2003 tentang Sistem Pendidikan Nasional, dalam Nugraha \& Rahmatiani, (2017) yang berbunyi bahwa "suatu tujuan pendidikan nasional yaitu adalah mengembangkan potensi peserta didik agar menjadi manusia yang selalu beriman, bertakwa kepada Tuhan Yang Maha Esa, berakhlak yang mulia, sehat, berilmu, cakap, kreatif, mandiri, dan menjadi warga negara yang demokratis serta bertanggung jawab. Pengertian pendidikan tersebut secara umum mengatakan bahwa pendidikan adalah sarana membangun manusia Indonesia sebagai insan paripurna" (hal. 56). Pendidikan Pancasila juga mempunyai tujuan untuk membentuk sikap siswa di sekolah menjadikan sikap serta prilaku yang bermoral, dan berwawasan luas. Sesuai dengan tujuan pendidikan Pancasila yang juga bertujuan untuk menghasilkan siswa yang berprilaku sesuai dengan tujuannya menurut Kaelan (2016) mengatakan sebagai berikut "dapat memiliki kemampuan untuk mengambil sikap yang bertanggung jawab sesuai dengan hati nuraninya, memiliki kemampuan untuk mengenali masalah hidup kesejahteraan serta cara-cara pemecaannya, dan mengenali perubahan dan perkembangan ilmu pengetahuan, teknologi, dan seni" (hal. 6).

Saat kegiatan belajar mengajar berlangsung tentu dengan mengguakan model pembelajaran yang menarik yang dapat memudahkan guru dalam kegiatan pembelajaran agar siswa juga mudah memahami materi pembelajaran serta ikut berpatisipasi didalam kelas. Model pembelajaran digunakan untuk memecahkan suatu masalah yang dihadapi ataupun untuk menjawab suatu pertanyaan yang berbeda dengan model yang digunakan untuk tujuan agar siswa mampu berfikir dan mengemukakan pendapat sendiri. Permendikbud Nomor 65 Tahun 2013 mengamatkan bahwa "dalam proses pembelajaran pada satuan pendidikan harus diselenggarakan secara interaktif, inspiratif, menyenangkan, menantang, selalu dapat memotivasi siswa untuk berpartisipasi aktif, serta memberikan ruang yang cukup bagi siswa, sesuai dengan bakat minat, dan perkembangan fisik bagi siswa".

Kurikulum 2013 berbeda dengan kurikulum 2006 yang menyampaikan pembelajaran masih dengan cara ceramah dan tidak semua siswa dapat menangkap pembelajaran dengan cara tersebut, kurikulum 2013 siswa diarahkan untuk lebih aktif dalam kegiatan pembelajaran (student center). Agar penyampaian materi lebih menarik digunakan beberapa model pembelajaran yaitu salah satunya dengan model Problem Based Learning (PBL) yang perlu dipelajari oleh sebagian guru-guru jika mungkin belum memahami dalam menyampaikan cara belajar kepada peserta didik. Tetapi pada kenyataannya saat ini masih banyak proses pembelajaran yang berpusat pada guru. Sementara itu menurut Tan (2003) dalam Amir (2016) mengatakan bahwa "pelajaran PBL akan atau dapat dimulai dengan pemberian masalah biasanya masalah memiliki konteks dengan dunia nyata yang sesungguhnya, pembelajaran secara berkelompok yang aktif serta kreatif merumuskan masalah, mengidentifikasi kesenjangan pengetahuan mereka mempelajari serta mecari sendiri materi yang terkait dengan masalah dan melaporkan solusi masalah" (hal. 12).

Agar kegiatan belajar mengajar berlangsung dengan menarik dapat digunakan model pembelajaran yang berbasis pemecahan masalah. Siswa dapat lebih aktif dalam berdiskusi dengan teman kelompok belajar untuk memecahkan masalah yang ada pada meteri pembelajaran. Pembentukan tim kelompok belajar pada siswa juga dapat memudahkan siswa untuk berdiskusi untuk mencari informasi yang akurat pada permasalahan yang ada dimateri pembelajaran. Pada saat 
pembelajaran berlangsung model PBL juga efektiftif dalam mempelajari pengetahuan tertentu menurut Woods (2000) mengatakan sebagai berikut bahwa "PBL lebih dari sekedar lingkungan yang efektif untuk mempelajari pengetahuan tertentu. Bahwa dapat memberi pembelajar membangun kecakapan sepanjang hidupnya dalam memecahkan masalah, kerja sama tim, dan berkomunikasi" (hal. 13).

Model pembelajaran PBL menyiapkan siswa untuk berpikir secara kritis, analitis, dan mampu untuk mencari sumber- sumber informasi. Untuk mendapatkan serta menggunakan secara tepat sumber-sumber pembelajaran baik melalui internet, buku PPKn, dan buku- buku yang ada atau disediakan di perpustakan sekolah. Pada model pembelajaran PBL ini juga dapat digunakan untuk menumbuhkan kreativitas belajar pada siswa menurut Campbell (2017) dalam Sunarto (2018) kreativitas dapat diartikan yaitu adalah "dalam arti kreativitas dapat diartikan pertama yaitu kemampuan menanggapi, menanggapi dan memberikan jalan keluar segala pemecahan yang ada, kedua yaitu kemampuan melibatkan diri pada proses penemuan untuk kemaslahan, ketiga yaitu kemampuan intelegensi, gaya kognitif, dan kepribadian/motivasi, keeampat yaitu kemampuan untuk menghasilkan atau mencipta sesuatu yang baru oleh karenanya kreativitas ini didasari dengan kelenturan kelancaran kecakapan kepandaian" (hal. 35).

Saat kegiatan belajar berlangsung suasana, dan kondisi juga dapat mempengaruhi. Sarana serta prasarana pendukung pembelajaran juga dapat membantu menciptakan suasana kelas yang kondusif, dan nyaman. Selain itu kelas yang bersih, hangat, dan nyaman juga dapat mendukung kegiatan belajar siswa. Suasana dalam belajar juga perlu diperhatikan iklim belajar juga perlu dibentuk dalam suasana yang nyaman dikelas menurut Nugraha (2018) "suasana belajar juga mendukung suksesnya peserta didik dalam belajar yaitu suasana dalam belajar atau disebut juga iklim dalam belajar atau bisa disebut juga atmosfer belajar merupakan sebuah hal yang sangat penting dibalik suksesnya sebuah pembelajaran dilaksanakan. Iklim belajar perlu dibentuk dalam suasana yang layak untuk belajar agar membuat pebelajar merasa nyaman dalam menuntut ilmu dan mengembangkan keilmuannya. Iklim belajar yang nyaman perlu dibentuk oleh seluruh lapisan yang terkait dalam pendidikan. Iklim belajar perlu dibentuk dalam suasana yang layak untuk belajar agar membuat peserta didik merasa nyaman dalam menuntut ilmu" (hal. 29).

Penelitian ini dilatarbelakangi oleh penelitaan terdahulu yang relevan yang pertama dilakukan oleh (Fani Sicelia Dewi, 2015) di UNS dalam penelitiannya yang berjudul Penerapan Model PBL Untuk Meningkatkan Kemampuan Berfikir Kritis dan Sikap Demokratis Pada Mata Pelajaran PPKn Kelas VIII SMPN 8 Semarang mengatakan bahwa Pelaksanaan PBL meningkatkan kemampuan berpikir kritis adalah dengan cara membuat rumusan masalah, kelompok diskusi, kemampuan menyampaikan pendapat secara kritis. Penelitian terdahulu yang kedua dilakukan oleh (Andreas E.A. Wijaya 2014) di UNY dalam penelitian yang berjudul Pengaruh Kreativitas dan Gaya Belajar terhadap Hasil Tugas Akhir Siswa Mata Pelajaran Pengoprasian dan Perakitan Sistem Kendali di SMKN 2 Yogyakarta mengatakan bahwa kreativitas dalam penelitian ini sangat berpengaruh besar terhadap keberhasilan perancangan tugas akhir siswa. Berdasarkan uraian tersebut maka dapat disimpulkan model PBL adalah model pemebelajaran berbasis pemecahan masalah yang ada. Model PBL juga dapat menumbuhkan kreativitas belajar PPKn dengan memecahkan permasalah dalam diskusi kelompok di kelas.

\section{Metode}

Metode penulisan ini adalah menggunakan pendekatan kualitatif. Alasan dalam penelitian ini menggunkan pendekatan kualitatif adalah agar mudahnya penelitian yang diakukan di sekolah. Pemakaian metode penelitian kualitatif peneliti melakukan wawancara, observasi dan dokumentasi. Masih ada faktor-faktor dalam penelitian menggunakan pendekatan kualitatif yang mempengaruhi antara lain waktu dan keadaan sekarang yang sedang melaksanakan Pembatasan Sosial Bersekala 
Besar (PSBB) karna adanya pandemi virus covid-19 selanjutnya melakukan wawancara melalui daring menggunakan google from. Penelitian ini metode yang digunakan adalah metode observasi, dan wawancara. Metode ini digunakan karena agar mengetahui apaka model PBL dapat menumbuhkan kreativitas belajar PPKn di kelas X Akuntansi 4. Teknik analisi data menggunkan pengumpulan data, reduksi data, dan penyajian data. Subjek yang digunakan dalam motode ini adalah 2 guru PPKn dan 4 siswa X Akuntansi 4. Tempat dalam penelitian ini adalah SMKN 2 Karawang.

\section{Hasil dan Pembahasan}

Penerapan kreativitas belajar pelajaran PPKn dirasa baik diterapan di kelas X Akuntansi 4 karena model PBL ini model berbasis pemecahan masalah yang dimana siswa menjadi lebih aktif, kreatif, dan berani untuk menyuarakan pendapatnya serta gagasannya. Berdasarkan observasi di SMKN 2 Karawang peneliti menemukan beberapa faktor permasalahan yang terjadi pada siswa kelas $X$ Akuntansi 4, seperti rendahnya kreativitas belajar dalam mengerjakan tugas-tugas yang diberikan oleh guru PPKn. Hal tersebut dilihat dari sikap belajar saat masih bersekolah di Sekolah Menengah Pertama menuju ke Sekolah Menengah Kejuruan. Penelitian yang telah dilaksanakan di SMKN 2 Karawang bukan berarti pula menyatakan bahwa tidak adanya halangan dalam penerapan model PBL ini. Subjek dari penelitian ini yaitu 1 guru PPKn kelas X Akuntansi 4, 1 orang guru kelas XI, dan orang siswa X Akuntansi 4. Akan tetapi dalam penelitian ini, peneliti ingin mengetahui apakah model PBL dapat menumbuhkan kreativitas belajar mata pelajaran PPKn.

Menurut hasil wawancara dengan responden. Menggunakannya model PBL dalam kegiatan belajar mengajar siswa lebih kreatif dan aktif untuk mengerjakan tugas yang diberikan oleh guru baik dalam tugas kelompok, membuat Power Point, dan mempersentasikannya pada siswa kelas $X$ Akuntansi 4. Sesuai dengan kurikulum 2013 siswa diminta lebih kreatif, dan aktif dalam kegiatan belajar. Cara menerapkan jiwa kreativitas belajar siswa dalam mengajukan gagasan pemecahan suatu masalah yang ada kelompok belajar adalah mempersipkan materi, memberikan kesempatan kepada kelompok lain untuk menampaikan gagasannya, dan selalu dipantau oleh guru pengajar supaya mendapatkan hasil baik karna aka nada kreativitas dalam kelompok belajar tersebut. Menciptakan kelas yang aktif dan kreatif dalam kelas $X$ Akuntansi 4 yaitu memberikan pembahasan yang menarik untuk dibahas, dan menciptakan diskusi antara siswa dan guru. Urutan atau tata cara yang dibutuhkan dalam mengerjakan tugas membuat slide Power Point pada mata pelajaran PPKn di kelas $X$ Akuntansi 4 yaitu harus ada penjelasan yang jelas, dan menyimpulkan lalu menjadikan point yang jelas berdasarkan sub kompetensi kesimpulan yang baik. Saat melakukan persentasi tugas mata pelajaran PPKn dapat dilakukan seefesien dengan jalannya diskusi dalam persentasi sesuai. Model PBL dapat menumbuhkan kreativitas belajar dalam mata pelajaran PPKn dengan memberikan tugas kelompok di kelas X Akuntansi 4 karena persentasi dengan Power Point membuat pemebelajaran lebih menarik, menciptakan pembelajaran lebih efektif, efesien, dan materi bisa disampaikan secara utuh dengan tampilan kreativiats slide yang menarik siswa akan belajar kebih senang bahkan bisa merangsang minat belajar siswa. Menerapkan atau menumbuhkan kreativitas belajar dalam mengajukan gagasan pemecahan masalah yang ada dalam kelompok siswa saat persentasi yaitu membina, memberi pemahaman bahwa setiap siswa adalah sumber belajar jangan pernah menyalahkan pendapat siswa, memberikan apresiasi positif pada setiap siswa yang berani menyampaikan gagasannya, memposisikan semua siswa sama, dan membimbing menghilangkan rasa minder serta rasa tidak percaya diri pada siswa. Menciptakan kelas yang aktif kreatif dalam $\mathrm{X}$ Akuntansi 4 melatih siswa untuk berani berpendapat, mendorong siswa terlibat dalam kerja sama dalam kelompoknya, memberi tugas siswa yang akhirnya mengapresiasikan dirinya secara kreatif, dan memberi reward sederhana pada siswa atau apresiasi positif bagi siswa yang mau menyampaikan 
gagasannya. Urutan atau tata cara yang dibutuhkan untuk mengerjakan tugas Power Point untuk menumbuhkan kreativitas belajar siswa pada mata pelajaran PPKn dengan cara memahami materi yang akan dibuat Power Point, materi yang ditulis dalam slide tidak keluar dari masalah yang dibahas, slide dibuat sesederhana mungkin tidak banyak tulisan, menggunakan latar terang maka tulisan dengan warna gelap, agar lebih menarik gunakan variasi warna serta gambar, dan gunakan maksimal tiga warna dalam slide. Melakukan persentasi di kelas X Akuntansi 4 dilakukan seefesien mungkin jangan memberikan masalah yang sulit untuk dipahami, slide yang menarik, gunakan aturan lima kata dalam satu kalimat tidak boleh lebih dari lima kalimat dalam satu slide, dan ketika persentasi jangan membaca terus namun menghadap audiens jangan membaca langsung pada slide agar persentasi menjadi aktif.

Hasil penelitian ini dari hasil wawancara dan observasi langsung dengan perwakilan dari SMKN 2 Karawang. dalam menerapkan model PBL ini cukup menarik, materi mudah dipahami karena dengan diterapkannya model ini siswa menjadi terlatih serta percaya diri dalam menumbuhkan kreativitas belajar, dan mengemukakan pendapatnya sehingga proses diskusi berjalan dengan baik. Meskipun tidak menutup kemungkinan masih saja ada beberapa hambatannya namun jika dilihat dari perkembangannya sebelumnya dirasa cukup baik siswa yang tadinya tidak percaya diri ketika mengeluarkan gagasannya sekarang sudah berani untuk mengemukakan gagasannya.

Mengembangkan kemampuan siswa agar mempunyai wawasan pengetahuan yang luas. Mempunyai sifat serta prilaku yang baik. Sesuai dengan Pasal 3 Undang-Undang Nomor 20 tahun 2003 tentang Sistem Pendidikan Nasional, dalam Nugraha \& Rahmatiani, (2017) yang berbunyi bahwa dalam "tujuan pendidikan nasional adalah mengembangkan potensi peserta didik agar menjadi manusia yang beriman dan bertakwa kepada Tuhan Yang Maha Esa, berakhlak mulia, sehat, berilmu, cakap, kreatif, mandiri, dan menjadi warga negara yang demokratis serta bertanggung jawab. Pengertian pendidikan tersebut secara umum mengatakan bahwa pendidikan adalah sarana membangun manusia Indonesia sebagai insan yang paripurna" (hal. 97). Hidup dalam berbangsa dan bernegara mempunyai ideologi. Ideologi negara Indonesia adalah Pancasila. Pancasila sebagai pandangan hidup bangsa arti dari Pancasila yang dijabarkan menurut Kaelan, (2013) dalam Sukadi (2017) yaitu menjelaskan bahwa "pancasila dapat dikatakan sebagai pandangan hidup, artinya pancasila memang merupakan suatu ide yang menjadi cita- cita bangsa. Pancasila sebagai pandangan hidup bangsa tersebut terkandung didalamnya konsepsi dasar mengenai kehidupan yang dicitacitakan, terkandung dasar pikiran yang terdalam dan gagasan mengenai wujud kehidupan yang baik" (hal. 97). Selain memiliki sikap bertanggung jawab tujuan dari pendidikan Pancasila dan Kewargangaraan juga arus bermakna dan berguna sebagai masyarakat dalam keidupan berbangsa dan bernegara menurut Rakhmat, (2015) mengatakan bahwa "tujuannya adalah untuk melangsungkan hidup dan kehidupan generasi penerus selaku warga masyarakat Bangsa dan Negara agar berguna dan bermakna" (hal. 16). Sedangkan arti tujuan dari Pendidikan Pancasila dan Kewarganegaraan bertujuan untuk menghasilkan siswa yang berprilaku sesuai dengan tujuannya menurut Kaelan (2016) sebagai berikut "memiliki kemampuan untuk mengambil sikap yang bertanggung jawab sesuai dengan hati nuraninya, memiliki kemampuan untuk mengenali masalah hidup dan kesejahteraan serta cara-cara pemecaannya, dan mengenali perubahan dan perkembangan ilmu pengetahuan, teknologi, dan seni" (hal. 6). Penyampaian pembelajara menggunakan model pembelajaran juga dapat menjadikan siswa aktif, kreatif, dan berani menyaimpaikan gagasannya. Penerapannya dengan beberapa model salah satunya model Problem Based Learning (PBL) yang perlu dipelajari oleh sebagian guru-guru jika mungkin belum memahami dalam menyampaikan cara belajar kepada peserta didik. Tetapi pada kenyataannya saat ini masih banyak proses pembelajaran yang berpusat pada guru. Sementara itu menurut Tan (2003) dalam Amir (2016) mengatakan bahwa "pelajaran PBL dimulai dengan pemberian masalah biasanya masalah memiliki konteks dengan dunia nyata, pembelajaran secara berkelompok aktif merumuskan 
masalah, mengidentifikasi kesenjangan pengetahuan mereka mempelajari serta mecari sendiri materi yang terkait dengan masalah dan melaporkan solusi masalah" (hal. 12).

Individu seseorang tentu memiliki kreativitas dan keahliannya masing-masing. Kreativitas bisa ditumbuhkan pada diri seseorang dengan terus mengasah kemampuannya secara terus menerus serta berani mencoba hal-hal baru. Dalam pembelajaran juga bisa menggunkan model pembelajaran agar terciptanya suasana belajar yang kreatif. Penggunaan model pembelajaran PBL ini juga dapat menumbuhkan kreativitas belajar dalam mata pelajaran PPKn di kelas X Akuntansi 4 yaitu menurut Campbell (2017) dalam Sunarto (2018) kreativitas dapat diartikan sebagai berikut adalah "kreativitas dapat diartikan kemampuan menanggapi, menanggapi, memberikan jalan keluar segala pemecahan yang ada, kemampuan melibatkan diri pada proses penemuan untuk kemaslahan, kemampuan intelegensi, gaya kognitif, kepribadian/motivasi, dan kemampuan untuk menghasilkan atau mencipta sesuatu yang baru" (hal. 35). Selain itu potensi yang dimiliki individu juga beragam. Kemampuan tersebut dapat diperoleh sejak lahir ataupun dipelajari ketika besar. Rasa ingin tahu yang besar juga merupakan bentuk dari kreativitas belajar karena disaat siswa ingin mengetahui sesuatu dalam pemebelajaran siswa akan mencari informasi yang akurat dan valid untuk dijadikan sebuah pengetahuan sehingga siswa menjadi kreatif. Kegiatan belajar mengajar juga mempunyai proses yang Panjang agar tercapainya tujuan dari pembelajaran. Proses pembelajaran akan lebih mempengaruhi atau berjalan lancar jika adanya timbal balik (feedback) antara siswa dan guru di kelas saat pembelajaran berlangsung.

Penjelasan tersebut dapat ditarik kesimpulan bahwa model Problem Based Learning (PBL) untuk menumbuhkan kreativitas belajar PPKn, menurut analisa peneliti bahwa hasil dari penerapan model PBL adalah siswa lebih akti, kreatif, dan berani menyampaikan gagasannya. Berdiskusi bersama teman kelompok belajar juga dapat membantu menumbuhkan kreativitas belajar, toleransi, bermusyawarah dalam pemecahan masalah dalam kelompok belajar. Kemudian berdasarkan hasil temuan penelitian bahwa model PBL di kelas X Akuntansi 4 serta menurut responden bahwa model PBL ini dapat diterapkan dalam pemeblajaran PPKn.

\section{Simpulan}

Berdasarkan temuan dan pembahasan yang telah diuraikan ini peneliti akan merumuskan beberapa beberapa simpulan sebagai intisari dari hasil penelitian sebagai berikut kesimpulan secara umum bahwa penerapan model Problem Based Learning (PBL) untuk menumbuhkan kreativitas belajar dalam mata pelajaran PPKn di kelas X Akuntansi 4 SMKN 2 Karawang dapat berjalan dengan baik dan semestinya. Hal tersebut dapat dilihat dari saat pelaksanaan pembelajaran di kelas ketika guru memaparkan materi kepada siswa, kegiatan belajar mengajar berlangsung, dan guru tidak begitu kesulitan dalam memberikan materi. Sehingga dalam pelaksanaan berlangsung sangat kondusif, siswa menjadi lebih kreatif, komunikasi guru dan siswa berjalan dengan baik, bahkan saling mengeluarkan pendapat satu sama lain, dan mendapat hasil yang baik kreatif dan menyenangkan. Selain kesimpulan umum terdapat juga kesimpulan khusus sesuai dengan rumusan masalah dalam penelitian ini yang diuraikan sebagai berikut penerapan model PBL dalam menumbuhkan kreativitas belajar PPKn dikelas sangatla bagus karena siswa lebih bisa mengembangkan kreativitas belajarnya dengan membentuk kelompok belajar dikelas untuk berdiskusi. Membuat slide power point dengan kreativitas yang dimiliki kelompok, mempersentasikan dengan semenarik mungkin, dan kreatif dalam tanya jawab menyuarakan gagasan yang dimiliki. Demikian pengaruh terhadap siswa dari hasil diterapkannya model ini ialah seringkali siswa kurang kreatif menjadi kreatif meski tidak $90 \%$ semua siswa yang kurang kreatif menjadi kreatif. Tetapi secara tidak langsung mendapat wawasan yang luas yang didapatkan hasil dari diskusi bersama teman sebaya atau kelompok belajar. 
Ucapan Terima Kasih

Puji syukur kami panjatkan kehadirat Allah SWT, karna atas berkat, ramat, dan karunianya kami bisa menyelesaikan penelitian ini yang berjudul "Penerapan Model Problem Based Learning (PBL) untuk Menumbuhkan Kreativitas Belajar dalam Mata Pelajaran PPKn di Kelas X Akuntansi 4 SMKN 2 Karawang" dalam waktu yang sesuai dengan target yang dijadwalkan.

Ucapan terimakasih saya ucapkan kepada Bapak Dr. H. Dedi Mulyadi, S.E., MM., selaku Rektor Universitas Buana Perjuangan Karawang; Bapak Dr. H. Tarpan Suparman, S.Pd., M.Pd., selaku Dekan Fakultas Keguruan dan Ilmu Pendidkan Universitas Buana Perjuangan Karawang; Bapak Yogi Nugraha, M.Pd., selaku Ketua Program Studi Pendidkan Pancasila dan Kewarganegaraan Universitas Buana Perjuangan Karawang; Para Dosen PPKn Universitas Buana Perjuangan Karawang; Kepala Sekolah, Kesiswaan , dan guru- guru SMKN 2 Karawang; Keluarga penulis; teman-teman penulis; dan temanteman mahasiswa PPKn Universitas Buana Perjuangan Karawang.

\section{Referensi}

Amir, M. T. (2016). Inovasi Pendidikan Melalui Problem Based Learning (Ke-1). Kencana.

Dewi S. Fani. 2015. Penerapan Model PBL Untuk Meningkatkan Kemampuan Berfikir Kritis dan Sikap Demokratis Pada Mata Pelajaran PPKn Kelas VIII SMPN 8 Semarang. Skripsi. Semarang: Universitas Negeri Semarang.

M.S, Kaelan. (2016). Pendidikan Pancasila (Ke-11). Paradigma.

Muhammad Rakhmat, H. (2015). Pendidikan Pancasila \& Kewarganegaraan-academiaedu

Nugraha, Y., (2018). Iklim Belajar Sebagai Pendukung Penerapan Model Pembelajaran Jatidiri Bangsa. Jurnal Civic, 3 (1), 28

Nugraha, Y., \& Rahmatiani, L. (2017). Pelaksanaan dan Peran Kegiatan Ekstrakurikuler dalam Pembinaan Karakter Disiplin Siswa. Konferensi Nasional Kewarganegaraan III, November, 96102.

Nugroho, W. (2019). Pengaruh layanan mediasi terhadap perilaku bullying. Jurnal Medi Kons, 5(2), 103-114. http://ejurnal.unisri.ac.id/index.php/mdk/article/download/3189/2682

Kemendikbud. (2013). Permendikbud No.65 tentang standar proses pendidikan dasar dan menengah. Jakarta: Kementrian Pendidikan Kebudayaan.

Sambada, D. (2012). Peranan Kreativitas Siswa Terhadap Kemampuan Memecahkan Masalah Fisika Dalam Pembelajaran Kontekstual. Jurnal Penelitian Fisika Dan Aplikasinya (JPFA), 2(2), 37. https://doi.org/10.26740/jpfa.v2n2.p37-47

Siagian, R. E. F., \& Nurfitriyanti, M. (2015). Metode Pembelajaran Inquiry dan Pengaruhnya terhadap Hasil Belajar Matematika ditinjau dari Kreativitas Belajar. Formatif: Jurnal IImiah Pendidikan MIPA, 2(1), 35-44. https://doi.org/10.30998/formatif.v2i1.85

Suarbawa, I. P. (2019). Penerapan Model Problem Based Learning (Pbl) Pada Mata Pembelajaran Corel Draw Untuk Meningkatkan Hasil Belajar Di Ranah Psikomotor. Indonesian Journal of Educational Research and Review, 2(2), 162-171. https://doi.org/10.23887/ijerr.v2i2.17624

Sukadi, I., \& Si, M. (2017). Jurnal Pendidikan Pancasila Kewarganegaraan dan Hukum. Jurnal Pendidikan Pancasila Kewarganegaraan Dan Hukum, 1, 1-54.

Sunarto, S. (2018). Pengembangan Kreativitas-Inovatif Dalam Pendidikan Seni Melalui Pembelajaran Mukidi. Refleksi Edukatika: Jurnal Ilmiah Kependidikan, 8(2). https://doi.org/10.24176/re.v8i2.2348

Wijaya A.E. Andreas. 2014. Pengaruh Kreativitas dan Gaya Belajar Terhadap Hasil Tugas Akhir Siswa Mata Pelajaran Pengoprasian dan Perakitan Sistem Kendali di SMKN 2 Yogyakarta. Skripsi. Yogyakarta: Universitas Negeri Yogyakarta. hlm. 10-16 
Yayinta Maharani Puspita Putri, Yogi Nugraha, Tridays Repelita. Penerapan Model Problem Based Learning (PBL) untuk Menumbuhkan Kreativitas Belajar dalam Mata Pelajaran PPKn

Wiyono, T. (2018). Pengaruhmotivasi siswa dan kreativitas belajar terhadap hasil belajar PKn siswa. Citizenship Jurnal Pancasila Dan Kewarganegaraan, 6(2), 90. 